\title{
POTENCY THERAPY IN GLASSICAL INDIAN MEDICINE
}

\author{
KeNNETh G. ZYSK
}

\begin{abstract}
This paper examines the traditional Indian ideas about impotency, virility, and potency therapy as found principally in the Sanskrit medical treatises of Caraka and Suśruta. Included is a detailed discussion of the potency formulas and what they contain. The analysis of this material leads to six important conclusions: 1. Caraka relies on a brahminic explanation of and justification for potency therapy, which is wanting in Suśruta. 2. The use of symbolism to empower certain medicines seems to reflect a local tradition of folk medicine. 3. Certain animals are used as potency symbols. A similar use of potent animals occurs throughout Sanskrit literature. 4. The mention of meat in the potency of formulas of both treatises indicates that meat-eating was not forbidden at this time in certain contexts. 5. All but one of the potency formulas were to be consumed, and where believed to give general nourishment and bodily strength. Moreover, the consumption of animal semen as an ingredient in certain formulas was forbidden by the twelfth century CE. 6. The only non-consumed potency medicine was a foot balm, which may have been derived from an early tradition of Indian eroticism, known as Kāmaśāstra.
\end{abstract}

Virility and impotency are real concerns for people the world over, for they lie at the very basis of the survival of the species. All cultures have developed methods for curing impotency and assuring virility, which have focused on ways to increase and sustain the male sex drive through the consumption of aphrodisiacs and their application to the genitalia.

Some aphrodisiacs seem to be merely symbolic, such as the horns of certain animals used in China. Others have mysterious qualities, such as magic pills, potions, or salves. Here in the West, we may recall the whimsical aphrodisiac-formula called 'Love Potion \#9', famous from the 1950's hit song by the black vocal group, 'The Coasters'. (As I recall, it 'smelled like turpentine and looked like Indian ink', but the effects were apparently fantastic. It caused the man to kiss 'everything in sight', even 'a cop down on Thirty-Fourth 
and Vine', who then broke the 'little bottle of Love Potion $\# 9^{\prime}$.) ${ }^{1}$ Finally, we should not forget, Viagra, more recently developed by Pfizer Pharmaceuticals and sold the world over.

In India, where male virility is backed up by Hindu Law (dharma), the promotion and sale of aphrodisiacs are highly visible. Nearly every Indian newspaper routinely carries advertisements about wonder drugs that promise male potency and assure male offspring. Special potency clinics and virility specialists are found in almost every city, town, and village. Male potency is a thriving industry in India today.

In this paper, I should like to travel back in time to examine the traditional Indian ideas about impotency, virility, and potency therapy (väjikarana), as presented principally in the two classical treatises of Indian medicine, the Caraka- and Suśruta-Samhitās. These two works date from a few centuries before to a few centuries after the common era. They will be supplemented by the later transmission of similar notions in the two seventh-century compilations of Vāgbhața the Elder and of Vāgbhața, respectively the Asțāngasamgraha and Asțāngahrdayasamhitā, and by commentators to the classical treatises. This later documentation will illustrate certain changes and continuities in the traditional understandings at different points in time.

The commentators on the Caraka Samhitā include Jejjața, who probably lived in the seventh century; ${ }^{2}$ Cakrapannidatta, who was born in Bengal in the first half of the eleventh century; ${ }^{3}$ and Kavirāja Gangādhara Rāy, who also was born in Bengal in $1799 .{ }^{4}$ The commentators on the Suśruta Samnhitā include Dalhana, who may have lived in Ankkolā, near Mathurā, in the last quarter of the twelfth century, ${ }^{5}$ and Hārānacandra, who was a pupil of Kavirāja Gañgādhara Rāy in Bengal. He wrote his commentary in the late nineteenth and early twentieth centuries and died in $1935 .^{6}$

Both textbooks discuss the subject-matter in the chapter devoted to 'Vājikarana' or potency therapy, which is found in the 'Book of Therapeutics' (Cikitsāsthāna) in the two compilations and have much

\footnotetext{
For lyrics see http://er.neorxer.com/3/searchers.html

Meulenbeld 1999-2002, 1A: 191-94, 597-602; 1B: 295-300, 677-81.

${ }^{3}$ Meulenbeld 1999-2002, 1A: 182-85; 1B: 284-86; 2A: 92-93; 2B: 110-11.

${ }^{4}$ Meulenbeld 1999-2002, 1A: 186-87; 1B: 287-89.

${ }^{5}$ Meulenbeld 1999-2002, 1A: 376-79; 1B: 496-99.

${ }^{6}$ Meulenbeld 1999-2002, 1A: 383-84; 1B: 504-05.
} 
in common with each other. However, there are important differences. Caraka's chapter is longer and more comprehensive, including more recipes than Suśruta's. Moreover, Caraka's discussion occurs as the second chapter in the Cikitsāsthāna and is divided into four quarters $(p \bar{a} d a)$, each of which contains a set of potency-formulas. The first recipe in each quarter serves as the basis for the remaining formulas in the quarter and is therefore the most important recipe of the quarter. Suśruta's discussion, on the other hand, is more concise, covering the subject in just thirty verses of the twenty-sixth chapter of his Cikitsāsthāna.

Although the process of compilation is unknown, it seems likely that each of the four quarters in the Carakasamhitā could represent a separate and different collection of formulas, which were combined into one chapter over the course of time. On the one hand, each of the four sections forms a separate set of formulas, and, on the other, the general information is sometimes repeated in different sections.

Caraka begins his discussion with the social justification for potency therapy, which in Suśruta is conspicuous by its absence. The differences in the two authors' presentation of the subject could help to establish a relative chronological relationship between the information about potency therapy assembled in the two works. The absence of descriptions of the social context for potency therapy in Suśruta may indicate merely that the acceptable reason for the use of aphrodisiacs was widely known and accepted, and, therefore, need not be mentioned. However, if examined historically, it could suggest something rather more significant. In addition to Suśruta's brevity, there is also considerable conciseness and a noticeable absence of theoretical background and explanation. Rather than a distillation of information, these points could suggest that Suśruta's compilation represents an early, more authentic version of potency therapy in which only the most essential information, namely, the recipes and their efficacy, were included, without reference to brahminic ideology. By the time potency therapy reached its final version in the Caraka Samhitā, it consisted of more recipes and included explanations and rationales based on brahminic social values and ideals, reflecting what I elsewhere have explained as the 'Hindu veneer' superimposed on an already pre-existing body of Indian medical information in order to make it authoritative literature. ${ }^{7}$ The brahminic

\footnotetext{
7 Zysk 1998, pp. 6, 21-37; Zysk 1999, pp. 125-45.
} 
rationale for sexual intercourse, running through all the books that deal with Hindu law or Dharma, is quite simply procreation, in particular the production of a male offspring. Typical of patri-lineal cultures such as that of brahminic India, is the thinking that sons assure the continuity of the family and the clan over time. In this way, traditional Indian potency therapy was meant exclusively for men. Moreover, sexual enhancements and any means to increase male virility must necessarily have impregnation and the generation of (male) offspring as their principal purposes. Caraka spells this out very clearly.

As a solitary, single-branched, and bad-smelling tree that casts no shadow, so also is the childless man. [Like] a lamp in a picture, a dry lake, [and] non-metal that resembles metal, the issueless man is [but] a figure of a man, who should be regarded as 'a grass-stuffed [effigy]'. A man, of whom no offspring is known, should be considered as without social rank, exposed, empty, with only one sense faculty, and without action. He, who has numerous offspring, has many shapes, mouths, bodily forms, actions, eyes, ways of knowing, and selves. The man, who has many offspring, is praised [thus]: 'he is auspicious; he is praiseworthy; he is fortunate; he is powerful; and he is multi-branched'. Fondness, strength, happiness, livelihood, expansion [of family lineage], respectability, nobility, fame, the worlds, which have happiness as the end result, and satisfaction - [all these] depend on offspring. Therefore, he, who seeks offspring, and the qualities dependent on offspring, and, he, who seeks pleasures from carnal love, should daily use potency therapy. ${ }^{8}$

In a language reminiscent of the brahminic Lawbooks (Dharmaśāstras), Caraka recommends that '[a] self-determined young man should daily seek potency therapy, for, on what does duty (dharma) prosperity (artha) depend, likewise, fondness (priti) and fame (yasas), surely, it is the abode of a son; and these qualities have sons as their seats'. ${ }^{9}$ With the help of the commentators, we understand that Caraka establishes an inextricable connection between righteousness (dharma) and potency therapy. When an intelligent young man uses potency therapy for the purpose of procreation, as sanctioned by Dharma, he becomes sexually aroused, which leads to intercourse resulting in a male issue who, according to the dharmic rule, effects his father's

${ }^{8}$ Caraka Samhitā, Cikitsāsthāna 2.16cd-23.

${ }^{9}$ Caraka Saṃhitā, Cikitsāsthāna 2.1 3-4ab. 
well-being both in this world and in the next. In this way, there is interdependence between the father's success, his sons, and the potency therapy he uses to obtain them.

Suśruta offers no such brahminic justification for the use of aphrodisiacs, opting instead for more medical reasons and explanations. Potency therapy (vajikarana), he says, has as its motive the filling out, the purification, the increase, and the production of insufficient, defective, weak, and dried up semen, and has as its purpose the production of sexual arousal. ${ }^{10}$

Having pointed out the fundamental difference between the two classical medical treatises, we can now focus on information which they share in common. Our investigation will, therefore, cover four topics: impotency; potency and virility and their images; potency therapy; and, finally, the potency formulas and recipes, i.e., the aphrodisiacs.

\section{Impotency}

In Sanskrit, the principal term for impotency is the neuter noun klaibya $(m)$. It derives from the adjective $k l i b a$, which, in addition to 'impotency', means a 'eunuch', and in the tradition of Sanskrit grammar, it refers to the neuter gender."

Caraka equates impotency with the want of semen, which occurs naturally in both pre-pubescent boys and in old men, and can also have unnatural causes, such as anxiety, disease, injury, fasting, and excessive coitus. ${ }^{12}$ Suśruta, in a somewhat more elaborate fashion, identifies and discusses six types of impotency based on their causes:

Psychological impotency occurs when the mind is impaired by various unpleasant emotional states, such as fear, diffidence, looking at a defiled woman, and by intercourse with what were seen to be despicable women;

${ }^{10}$ Suśruta Saṃitā 1.8.8.

1 The verbal root, from which this is formed, $k \bar{l} b$, attested primarily in grammatical texts, means, according to the Sanskrit dictionary of Monier-Williams, 'to be impotent, to behave like a eunuch', p. 324.

12 Caraka Saṃhitā, Cikitsāsthāna 2.4.40-44. 
Food-caused impotency occurs when there is loss of the cool, moist bodily tissues (dhatus), characteristic of semen, due to the excessive consumption of spicy, sour, hot, and salty foods;

Semen-loss impotency occurs when the penis does not become erect due to the absence of semen caused by excessive coitus without taking recourse to potency therapy;

Injury-caused impotency is an injury to a man's masculinity, and occurs when there is damage either to the penis or to the seminal duct, which is one of the body's vulnerable spots (marman);

Congenital impotency occurs in a man who is impotent from birth;

Celibacy-caused impotency occurs when the semen becomes thick and dry (some say, old) because there is suppression of the natural urges due to the practice of celibacy (brahmacarya).

Of these six, only congenital and injury-caused impotencies are incurable. The remaining four can be cured by potency therapy. ${ }^{13}$ Suśruta's six types of impotency, therefore, supply the technical information wanting in the Caraka Samhitā. In addition to being the desired opposite of impotency, virility and potency are treated both colourfully and technically by Caraka and Suśruta.

\section{Virility and potency}

The main Sanskrit words for virility and potency are virya (which is often glossed by the commentators as sukra, 'semen') ${ }^{14}$ and väjin (which, as an adjective, means 'heroic' or 'manly' and, as a masculine noun, 'a steed' or 'a stallion'). Drawing on analogies from the animal world, which is common in Indian literature, both Suśruta and Caraka characterise a potent man as a virile stallion (väjin), who is able to copulate with numerous females in succession without tiring. ${ }^{15}$ Other examples from the animal kingdom include a male elephant (gaja), which is known to ejaculate abundant semen; ${ }^{16}$ a male sparrow (cataka;

${ }^{13}$ Suśruta Saṃitā, Cikitsāsthāna 26.9ef-15.

${ }^{14}$ See especially Cakrapānidatta to Caraka Saṃhitā, Cikitsāsthāna 2.1.16cd-24ab, and 2.2.32.

${ }_{15}$ Caraka Saṃhitā, Gikitsāsthāna 2.2.33b; 2.2.13c, 29c, 30c, 51; Suśruta Saṃhitā, Cikitsāsthāna 26.30.

${ }^{16}$ Caraka Saṃhitā, Cikitsāsthāna 2.2.29d; 2.4.6. 
kulinga), which is recognised as staying aroused for an exceptionally long time, visiting female birds one after the other; ${ }^{17}$ and a bull (vrs $a$ ), whose very nature indicates strength, power, and virility. ${ }^{18}$

The dominant physical characteristics of virility, occurring in both textbooks, include the following: youthfulness, ${ }^{19}$ strength,${ }^{20}$ sexual arousal, ${ }^{21}$ good complexion and strong voice, ${ }^{22}$ physical size or bulk, ${ }^{23}$ an erect penis, ${ }^{24}$ and inexhaustible semen..$^{25}$

Caraka connects virility with semen, which he explains as the male power (sakti) produced from sexual arousal, which, in turn, depends on the strength of body and mind. ${ }^{26}$ This semen, generated from sexual stimulation, is then ejaculated during coitus, and, when healthy, bears fruit.

As the juice in sugar cane, the fresh butter in curds, and the oil in the sesame seed, so also semen is penetrated everywhere in the body part with the sensation of touch [i.e., arousal].

The semen streams forth from its source during sexual intercourse between a man and a woman because of movement, mental resolve, and squeezing, like water [streams forth] from a wet cloth [when it is squeezed]. The semen, which is called the substratum of the moving, multi-formed [soul], flows forth from the body because of these eight causes: sexual arousal, erotic thirst, fluidity, sliminess, heaviness, minuteness, emission, and the propulsion of wind. Without doubt, that semen is fruitful, which is viscous, sweet, unctuous, not-putrid smelling, heavy, slimy, white, and abundant. ${ }^{27}$

Semen, therefore, is the critical indicator of virility. For both Caraka and Suśruta, potency therapy is the means to increase semen, virility,

${ }^{17}$ Caraka Samnhitā, Cikitsāsthāna 2.4.6; Suśruta Saṃhitā, Cikitsāsthāna 26.36.

${ }^{18}$ Caraka Saṃhitā, Cikitsāsthāna 2.4.7d.

19 Caraka Saṃhitā, Cikitsāsthāna 2.2.17d; Suśruta Saṃhitā, Cikitsāsthāna 26.29b.

${ }^{20}$ Caraka Saṃhitā, Cikitsāsthāna 2.1.45d, 50d; 22.23c, 26c, 30b; Suśruta Saṃhitā, Cikitsāsthāna 26.37.

${ }^{21}$ Caraka Saṃhitā, Gikitsāsthāna 2.1.33b; 2.2.17d, 20d, 23c, 26c, 27d, 30c.

${ }^{22}$ Caraka Saṃhitā, Cikitsāsthāna 2.1.41c; 2.2.23cd, 26c, 30b.

${ }^{23}$ Caraka Saṃhitā, Cikitsāsthāna 2.1.43c, 50d; 2.2.23d.

${ }^{24}$ Caraka Saṃhitā, Cikitsāsthāna 2.1.46c, 48ab; 2.2.13b.

${ }^{25}$ Caraka Saṃhitā, Cikitsāsthāna 2.1.46d; 2.2.9d.

${ }^{26}$ Caraka Saṃhitā, Cikitsāsthāna 2.4.45cd.

${ }^{27}$ Caraka Saṃhitā, Cikitsāsthāna 2.4.46-50. At 46b, all editions have dadhni sarpis tailam tile yatha, 'as clarified butter in curds, and oil in the sesame seed'. The reading of navanitam for sarpis tailam follows the commentator Jejjaț. In 46c, all editions have sarvatrānugatam, 'has penetrated everywhere'. The reading of sarvam cānugatam follows Jejjața. 
sexual stamina, and bodily size and strength - and particularly for Caraka, it is essential for progeny.

\section{Potency therapy}

Both Caraka and Suśruta include potency therapy in the list of the eight limbs (aștāinga) of āyurveda, and link it closely to rasāyana, the sub-discipline of āyurveda that involves rejuvenation therapy. ${ }^{28}$ Both authors explain rasāyana in the same way, but Caraka provides the most comprehensive definition. He says that it is the means by which a person

attains a long life-span; memory; intelligence; freedom from disease; youthfulness at all ages; excellent lustre; complexion and voice; the highest power of body and sense faculties; success in what he says; respectability; and handsomeness. Indeed, rasäyana is the means to acquire the cherished essential juices (rasa), etc. ${ }^{29}$

Rejuvenation therapy, therefore, aims at long-term beneficial effects by providing longevity as a result of a healthy and youthful body, and should only be used when it is required by the patient and prescribed by a qualified physician.

Potency therapy, on the other hand, aims at short-term effects and can be used every day if necessary. This therapy brings the body to the condition where abundant, strong semen can be ejaculated during coitus. The ultimate goal, according to Caraka, is the generation of offspring. Suśruta explains that it is the means by which a lustful man, acting like an impetuous stallion, satisfies a woman, and that, even when old, a man who uses such therapy can have coitus in all seasons. The different formulas are prescribed particularly for old men; for lustful men who desire the favour of women; for men who are weak due to coitus with young women; for men who are impotent; for men with little semen; for wealthy, handsome, and youthful gallants; and for men with many wives. In addition to the formulas, the following things make a man potent: diverse foods

\footnotetext{
${ }^{28}$ See Caraka Saṃhitā, Sūtrasthāna 30.28 and Suśruta Saṃhitā, Sūtrasthāna 1.7.

${ }^{29}$ Caraka Saṃhitā, Cikitsāsthāna 1.7-8; see also Suśruta Saṃhitā, Sūtrasthāna 1.8.7.
} 
and different drinks; [females'] speech friendly to the ear and skin pleasant to the touch; a night whose beauty mark (tilaka) is the moon; an affectionate girl in the prime of youth; songs charming to the ear; betel nut, fermented drinks, garlands, scents, charming forms, scenes, and gardens; and the absence of mental hindrances. ${ }^{30}$

Caraka uses a brahminic view-point to establish that a fertile woman is the aphrodisiac, par excellence. In both the Lawbooks (Dharmaśästras) and Textbooks of Erotic and Lawful Conjugal Love (Kāmaśástra and Ratiśāstra), it is acknowledged that a woman possesses the qualities that appeal to a man's senses and bring about his seduction. When a woman enters her monthly fertile period $(r t u)$, i.e., a length of time, which lasts for 16 days after her menses begins, she holds within her body the potential male offspring, which is the man's assurance of success as known from the brahminic perspective. It is precisely during this fertile period that her seductive qualities are most apparent. Therefore, she must prepare herself for intercourse and impregnation by taking a purifying bath at the cessation of her period and by going to her man's bed the very same night. This is explained in brief by Caraka, who also points out that there is a woman for every man.

Duty (dharma) and prosperity (artha), as well as good fortune (laksm $\vec{\imath}$ ), [are rooted] in women. The worlds are rooted in women. She, who has exquisite bodily form, who is youthful, who is adorned with auspicious marks, who is submissive, and who is instructed [in the sixtyfour arts], is considered to be the most sexually stimulating ...

Woman is man's sexual stimulant, because men have different states of mind. A healthy man, whose purpose is offspring, should make love to the woman who has been purified by [her postmenses] bath, who comes from a different clan, who is sexually stimulating, who is sexually aroused, and who is free from infirmities. ${ }^{31}$

\section{The formulas of potency therapy}

Whether for the production of a male issue, according to Caraka, or for heightened sexual pleasure, according to Suśruta, the best

\footnotetext{
${ }^{30}$ Suśruta Saṃhitā, Cikitsāsthāna 26.3-9cd.

${ }^{31}$ Caraka Saṃhitā, Cikitsāsthāna 2.1.6cd-8ab; 14cd-16ab. In 14c, all editions read gatuā gatuāpi. Reading of gatuā gatvā ca follows Jejjața.
} 
results are obtained when the formulas of potency therapy are properly used. These formulas are detailed in both textbooks and provide the most concrete understanding of aphrodisiacs and potency therapy in ancient India. For this reason, we shall examine them in detail.

Both Caraka and Suśruta state that the potency formulas should never be used without first cleansing the patient's body by means of the purification regimens involving purgatives and emetics; that they should be given in a dose that is in conformity with the patient's digestive power; and that after consumption, they should be followed by proper after-medication food or drink (annapāna).

Both authors devote the greatest amount of space to the specific formulas or recipes that constitute vājikarana. The total number from both books is 71: 21 in Suśruta and 50 in Caraka. No two recipes are exactly the same. Although both books include meat and nonmeat formulas, Caraka's collection, containing proportionally more meat recipes (22 meat and 28 non-meat, in contrast to Suśruta's 7 meat and 14 non-meat recipes), most likely derived the large number of its formulas from sources that favoured the use of meat. Moreover, the use of meat in the recipes from both collections suggests that the meat formulas originally derived from sources not dominated by brahminic ideology, and that the meat recipes might well be older than the non-meat ones. ${ }^{32}$

All formulas, except the one discussed below, are meant to be consumed as food. There are no recipes that are applied to the sexual organs, as one finds in books of Kāmaśāstra, like the Kāmasūtra and Ratirahasya. ${ }^{33}$ Although the recipes are different in each book, they all contain many of the same major ingredients, which, aside from some specialised herbs, have properties that add weight and bulk to the body.

Most of the non-meat recipes are vegetable based, containing as primary ingredients variations of the following: black gram $(m \bar{a} s a)$, cowage fruit ( $\bar{a} t m a g u p t \bar{a})$, asparagus (satavarn $)$, milky yam (vidarin), bamboo, wheat, barley, and white rice (sastika and sali). Often grapes,

${ }^{32}$ See K.G. Zysk (forthcoming) 'The Use of Animals in the Sanskrit Traditions of Lovemaking, Conjugal Love, and Medicine'.

${ }^{33}$ In both works, the recipes are found in the last chapter: Kämasütra, aupanisadikädhikarana, 2, and Ratirahasya, 15: sakalayogädhikarana. 
sugar-cane, or dates, are added, along with clarified butter and milk, and the whole thing is usually sweetened with ground white sugar and honey. There is also a symbolic association between male sexual organs and semen, and the different fruits, seeds, and plant stems used. The different recipes are prepared as pills, soups, fritters, different kinds of cakes, and medicated clarified butter. Milk (payas) is the other principal ingredient in non-meat formulas. It yields milk drinks, gruel, and potages.

The meat products consumed fall into three categories: animal flesh and fat eaten in the form of pills, soups, or meat patties and cakes; animal testicles and eggs; and animal semen. The latter two are consumed in the form of soups or fried dishes. Animal flesh and fat, like the non-meat recipes, add bulk and strength, while the testes and semen, through symbolic association, stimulate the sex drive. Flesh and fat come from the following animals: buffalo, pig, porpoise, various kinds of fish, as well as partridge, cock, peacock, swan, and sparrow, whose sexual exploits, as already noted, are well-known. Testicles come from rams, fresh water porpoises (?), and mice; eggs derive from crabs (?), tortoises, alligators, frogs, sparrows, fish, swans, peacocks, and chickens; and semen comes from buffaloes, bulls, rams, as well as, sparrows, swans, cocks, peacocks, fresh water porpoises, and alligators.

\section{Semen in Indian potency therapy}

Drinking animal semen as an aphrodisiac offers a special opportunity to observe continuity and change in the history of Indian medicine. Suśruta specifically prescribes drinking the semen of buffaloes, bulls, and rams. ${ }^{34}$ Both commentators, Dalhaṇa and Hārāṇacandra, however, categorically reject the practice on grounds that the tradition (i.e., the guru) strictly forbids it. In place of semen, they read testicles. In contrast, Caraka prescribes the collection and use of the semen from sparrows, swans, cocks, peacocks, fresh water porpoises, and alligators in a recipe that promises a man to have an erect penis full of semen and intercourse with many women like a stallion. ${ }^{35}$

${ }^{34}$ Suśruta Saṃhitā, Cikitsāsthāna 27ab.

${ }^{35}$ Caraka Saṃhitā, Cikitsāsthāna 2.2.10-13. It is possible that the semen referred 
Cakrapānidatta, repeating the earlier commentator, Jejjața, states that eggs (anda) must be read for semen (sukra) because it is impossible to collect semen from the animals mentioned above. Gangādhara, however, chooses to ignore both Jejjața and Cakrapānidatta, and maintains the reading as semen (śukra) ${ }^{36}$ In Vāgbhața the Elder's seventh-century compilation of medical knowledge, Astängasamgraha, the use of animal semen is nowhere mentioned in the chapter on potency therapy. The consumption and use of animal testicles, however, does occur. ${ }^{37}$ This indicates that originally, at the time of both Caraka and Suśruta, consumption of animal semen was permitted and practised. Vāgbhața the Elder, in the seventh century, rejected it by omission, and Jejjața, also in the seventh century, avoided it. This is followed almost verbatim by Cakrapannidatta in the eleventh century. Ganigādhara retains the reading, perhaps on account of academic Puritanism. Therefore, we can see that the once accepted practice of drinking animal semen as an aphrodisiac was widely discouraged by the seventh century, and was completely banned from general ayyurveda practice by the twelfth century. In the nineteenth century it appears to have been acknowledged in the available textual transmissions of the Caraka Samhita used by Gangādhara, but it is not clear if the consumption of semen was actually practised in ayyurveda at that time. The consumption of animals' testicles for medical purposes, on the other hand, never seems to have been prohibited.

One non-meat formula offered by Caraka indicates influence from a tradition that made symbolic use of ingredients in medical formulas. A special kind of thick milk should be obtained from a goodnatured and well-nourished cow that has eaten only leaves of black gram, sugar cane, or Arjun (arjuna) plants; that has four brown or black udders; whose horns point upwards; and whose first-born calf

to here was not really semen, but substances that resembled semen in appearance. In the case of the different kinds of fowl and the alligator, the resemblance could have been between semen and the albumin of their eggs; and the similarity in the case of the fresh water porpoise might well have been between semen and the mammal's fat, which elsewhere is called an aphrodisiac. In modern times, the name of a large sea mammal, the sperm whale, derives from a similar comparison between the animal's waxy spermaceti and semen.

${ }^{36}$ It is very possible that Gangādhara did not know Jejjata's commentary; but he certainly was familiar with Cakrapānidatta's.

37 Aștāngahṛdayasaṃhitā, Uttarasthāna, 50.86-87. 
is living and has its mother's colour. This milk should then be fortified by heating it by means of plunging circular leaves made of gold (mandala-jätarūpa) into the milk. Finally, clarified butter, honey, and sugar are added. This formula is said to provide offspring. ${ }^{38}$ Vāgbhața the Elder, who cites a close version of this passage, specifies that the leaves are very hot (sutapta); that the benefits from drinking the fortified milk include sexual excitement (vrsya) and male offspring (pumsavat); and adds that silver, iron, copper, or lead may also be used with the same result. ${ }^{39}$ According to Jejjața, the golden circular leaves contain variegated power (vicitrasakti). Following this, Cakrapaninidatta explains that the gold in the form of rings has a specific action (prabhāva) that facilitates the preparation of the potency formula. The milk becomes fortified by the specific action (prabhāva), i.e., the power (sakti), which is found in the circular shape of the rings.

There is evidence here of sexual symbolism: the thick, rich milk symbolises the male sperm, and the circle symbolises the female vagina. ${ }^{40}$ The passage from Caraka, repeated by Vāgbhața, points to a form of medicine that may have derived from a local folk tradition that recognised the importance of symbolic associations and the power they possessed. A similar notion of symbolism connected with the ideas of power (śakti) and specific action (prabhāva) seems to have occurred in the religious tradition of Tantrism, which was prevalent in north India by the seventh and eighth centuries.

\section{Foot-balm as potency formula}

The only formula that is not eaten or drunk is a foot-balm presented by Suśruta:

Clarified butter (ghrta) prepared with the testicles (anda) of an alligator (nakra) or a mouse (müsika), or the eggs (anda) of a frog (mandūka) or a

${ }^{38}$ Caraka Saṃhitā, Cikitsāsthāna 2.3.11.

39 Așțāngahṛdayasaṃhitā, Uttarasthāna, 50.102.

40 Some years ago, I observed a similar process in Pune, where heated gold leaves, mostly circular in shape, were plunged into milk. This was done, however, not for the purpose of fortifying the milk, but to purify the gold, which is an essential process in Indian medical alchemy before any metal can be used. 
sparrow (cataka) - [A man] makes himself strong by means of [this] foot balm (pädäbhyanga). But, he should not touch the ground. As long as he does not touch the ground, the man can have coitus without interruption. ${ }^{41}$

Vāgbhața the Elder offers a variant of this formula in two forms that use only vegetable ingredients:

After applying a foot-balm (pādalepa) [consisting of] long leaved barleria (adhyand̄ā), ārșabhī (rssbhaka), and cowage fruits (svayamguptāphala), a man does not lose [his] ability for sexual arousal throughout the night.

The foot-balm (caranalepa) [consisting of] hogweed root (varșäbhümüla), grapes (mrdvīka $)$, and cowage fruits (svayamguptāphala) is [also] successful. But, [the man] should not touch the ground with his foot. ${ }^{42}$

The idea that not touching the feet to the ground helps sustain sexual vigour occurs in yet another recipe given by Vāgbhața the Elder. In this case however, the formula is consumed by licking rather than being rubbed on the feet. The man, who licks the quantity of one picu (12 grams) of a preparation of herbs mixed with clarified butter and honey at dawn and who does not touch the ground with his feet, obtains strength and fortitude, and makes love to women like a stallion. ${ }^{43}$

The precise meanings of these special aphrodisiacs are not discussed by the different commentators, but similar recipes occur in two medieval ${ }^{44}$ Kāmaśāstra treatises, which prescribe that herbal balms should be applied to the feet in order to prevent premature ejaculation. ${ }^{45}$ It remains a mystery why the man was forbidden to walk or stand on the ground after the application. It is clear, however, that this is a unique type of aphrodisiac in the Indian medical tradition, which may have originated from traditions of Indian erotic love.

${ }^{41}$ Suśruta Saṃhitā, Cikitsāsthāna 26.31cd-32.

42 Asțāngahrụdayasaṃhitā, Uttarasthāna, 50.107-108.

43 Aș̣āngahṛdayasaṃhitā, Uttarasthāna, 50.38.

44 'Medieval' in the commonly used sense of the period of the Muslim invasions of India.

${ }^{45}$ Ratirahasya 15.25-26, and Anangaranga, 6.12-13. 


\section{Conclusions}

The investigation of the understanding of impotency, virility, and potency therapy in the early āyurvedic medical treatises reveals several important historical points and cultural characteristics.

First, Caraka relies on a brahminic social explanation of and justification for potency therapy, which is entirely wanting in Suśruta. The brahminic rationale for the inclusion of potency therapy in the Caraka Samhitā points to the 'Hindu veneer' that was superimposed on medical data and indicative of a somewhat later phase in the development of classical Indian medicine.

Second, the use of the power of symbolism to imbue milk with special qualities of sexual stimulation reflects perhaps a local tradition of folk medicine, which was incorporated into āyurveda through the Caraka Samhitā.

Third, both the Caraka Saṃitā and the Suśruta Sampitā utilise symbolic ideas that focus on animals to define potency and describe virility. A similar use of animal similes occurs throughout Indian literature.

Fourth, both treatises prescribe meat and non-meat based formulas to promote potency in men. This indicates that meat was freely used in general food preparations, and shows that at the time the eating of meat was commonly practised.

Fifth, all the formulas, with one exception, were meant to be consumed. None was applied to the genitalia. Moreover, their basic ingredients were aimed at providing general nourishment and promoting bodily strength. The consumption of certain animals' eggs and testicles, however, points to symbolic rather than nutritional usage. The eating of eggs and testicles was always permitted, but the drinking of animal semen, allowed in the earliest phase of Indian medicine, was discouraged by the seventh century and forbidden, perhaps on religious grounds, by the twelfth century, only to occur again in the text of a nineteenth-century commentary to the Caraka Samhitā.

Finally, the use of a foot balm as the only non-consumed formula points influences from an early tradition of Indian erotic love or Kāmaśāstra, where it is used to prevent premature ejaculation. It occurs first in Suśruta's collection and is preserved in the tradition, with variations, in the seventh-century compilation of Vāgbhata the Elder. Variations of it are found in two medieval Kāmaśāstra works, Ratirahasya and Anangaranga. 
Potency therapy or vājīkarana in the classical Indian medical treatises of Caraka and Suśruta, therefore, represents a diversified collection of medical information and formulas, reflecting different beliefs and cultural customs. In terms of the relative dates of the two compilations, Caraka's chapter on potency therapy on the whole appears to be the more recent, representative of an ongoing process of collection and assimilation of useful medial data.

\section{References}

[Āṭhavale, Ananta Dāmodara, ed.] Śrīmadvāgbhațaviracitah Aștāingasangrahah induvyākhyāsahitah sampādakah vaidya anaṃta dāmodara āțhavale ... śrīkṛ̦̣nāṣțamī, śake 1902, 1 September 1980 ... maheśa anamta ăthavale ... pune 4.

[Bhișagācārya Harīsāstrī Parāḍaka, ed.] Śrīmadvāgbhațaviracitah Aṣtāingahṛdayam aruṇadattaviracitayā sarvāngasundarākhyayā vyākhyayā, hemādripraṇîtayā āyurvedarasāyanāhvayā țịkayā ca samullasitam ... anṇā moreśvara kumte ..., kṛṣnaśāstrī navare ity etaiś ca pūrvam saṃskrtam . . . parāduakaropāhvena sadāśivasūnunā harišāstrinā bhiṣagācāryena samísodhitam ... ācāryapriyavrataśarmakṛtayā bhūmikayā ca saṃvalitam. Caukhambhā Orientalia ... Vārānasīi, Dillī, 1982 [Jayakṛ̣nnadāsa Āyurveda Granthamālā 52] [Originally published in 1939 by N.S. Press, Bombay].

[Candrakāntabhațtācārya, ed.] Suśrutasaṃitā | ciktsitasthānam | rāmapuraboyāliyāpravāsi-śrīhārāṇacandracakravarttikavirājaviracita-suśrutārthasandīpanabhāṣyasametam | bhūtapūrvvarājakīyasamskṛtavidyālayādhyāpakapūjyapādasarvvatantra-svatantratarkālanikārapadānkitamahāmahopādhyāyasvargīya-candrakāntabhaț̣ācāryya-pramukhaiḥ saṃśodhitam | kalikātārājadhānyāṃ ghoṣes-lenīya 16/1 saṃkhyakabhavanasthasatyayantre śrīsivavratacațtopādhyāyena mudritam | śrilayogeśacandravasākena kalikātārājadhānīyah prakāśitam | śakābdāh 1835 [A.D. 1912/13] | mūlyam — sārddhamudrāyam preșaṇavyayaś ca āṣakatrayam.

[Haridatta Śāstrin, ed.] Maharṣipunarvasuśișyeṇa ṛ̣ivareṇa agniveśena pranīiā mahāmuninā carakena kāpilabalena drḍhabalena ca pratisaṃkrtā Carakasamnitā mahāmahopādhyāyacarakacaturānanaśrīcakrapānidattaviracitayā Āyurvedadīpikāvyākhyayā (tathā cikitsāsthānatạ̣ siddhisthānaṃ yāvat) śrīvāgbhațaśișyācāryavarajajjațaviracitayā Nirantarapadavyākhyayā ca saṃvalitā | Âyurvedācāryeṇa Paṇ. Śrīharidattaśāstriṇā saṃsodhitā, pūritajajjațațīkātruțitāṃśabhāgā ca | dvitīyo bhāgah lavapurīyapañcābasamskrttapustakālayādhyakșaị śrīmotîlāl banārsīdās ity etaih svakīye "mumbai saṃskṛta" ity ākhye mudraṇālaya mudrāpayitvā prakāśitā | (dvitīyāvrttih) | sam 1997, san 1941 .

Meulenbeld, G. Jan 1999-2002, A History of Indian Medical Literature, 5 Parts in 3 Volumes, Groningen: Egbert Forsten.

Monier-Williams, Sir Monier 1990, A Sanskrit-English Dictionary, Oxford: Clarendon Press.

[Narendranātha Senagupta and Balāicandra Senagupta, ed. and rev.] Carakasaṃitā | mahāmuninā bhagavatāgniveśena praṇīā maharșicarakeṇa pratisaṃskṛtā carakacaturānanaśrīmaccakrapāṇidattapraṇītayā Āyurvedadīpikākhyațīkayā mahāmahopādhyāya-śrīgañgādharakaviratnakavirājaviracitayā Jalpakalpatarusamākhyayā țīkayā ca samalanikrtā kavirāja śrīnarendranātha senaguptena kavirāja śrībalāicandra senaguptena ca sampāditā saṃśodhitā prakāśitā ca | cikitsita-kalpa-siddhināmakasthānatrayasamanvitạ̣ tṛtīyaḥ khaṇḍah | prathamạ̣ saṃskaraṇam | 
si. ke. sena eṇu kompānī liḥl 29 nam kaluṭolā ștrīị, kalikatā | śakābdī 1855 [AD 1932/1933]. [Reprinted (from a later edition?) as caturthah khaṇạh, Vārānasī and Dillī: Chaukhambhā Orientialia, 1991; Vidyāvilāsa āyurvedagranthamālā 1].

[Rāmānanda Śarmā, ed.] 1994 Kokokakṛta Ratirahasyam kāñcīnāthakṛta 'dīpikā' saṃskṛta 'prakāśa' hindīṭāsahitam vyākhyākarah rāmānanda śarmā . . . Kṛ̣ṇadās Academy, Vārāṇasī [Kṛ̣ṇadās Samskṛt Series 142].

Śāstrin, Dāmodara Gosvāmin (ed.) 1982, Śrīvātsyāyanamunipraṇītam Kāmasūtram śrīyaśodharaviracita 'jayamañgalā' vyākhyāsahitam. Vārāṇasī, [Kāśī Saṃskṛta Granthamālā 29] [Reprinted with Hindī translation, translated and edited by Śrīdevadatta Sāstrī, Varanasi: Chaukhambha Sanskrit Sansthan].

Sharma, Priyavrat, (ed., and trans.) 1983, Caraka-Samhitā. Agniveśa's treatise refined and annotated by Caraka and redacted by Dṛ̂habala, (Text with English Translation), Volume II (Chikitsāsthānam to Siddhisthānam), Varanasi and Delhi: Chaukhambha Orientalia; Jaikrishnadas Ayurveda Series, 36.

Sharma, Priyayarat (trans.) 1994, Caraka-Samhitā. Critical Notes (Incorporating the commentaries of Jejjața, Cakrapāni, Gañgādhara and Yogīndranātha), Volume IV (Cikitsāsthāna to Siddhisthāna), Varanasi and Delhi: Chaukhambha Orientalia, Jaikrishnadas Ayurveda Series, 36.

Sharma, Priyayarat (ed. and trans.) 2000, Suśruta-Samhitā, with English translation of text and Dalhana's commentary along with critical notes, Volume II (Nidāna, Śārīra and Cikitsāsthāna), Varanasi: Chaukhambha Visvabharati; Haridas Ayurveda Series 9.

Singhal, G.D., R.H. Singh and K.P. Shukla (trans.) 1979, Non-operative Considerations in Ancient Indian Surgery (based on Suśruta Saṃhitā, Cikitsā-sthāna, Chapters 24 to 40), Varanasi: Singhal Publications.

Srikantha Murthy, K.R. (trans.) 1995, Vāgbhața's Asțāinga Hṛdayam (Text, English translation, Notes, Appendices and Indices), Volume III (Uttarasthāna). Varanasi: Krishnadas Academy; Krishnadas Ayurveda Series, 27.

- - (trans.) 1997, Asțāinga Samgraha of Vāgbhața (Text, English translation, Notes, Index), Volume III (Uttarasthāna), Varanasi: Chaukhambha Oriential; Krishnadas Ayurveda Series, 79.

[Trivikramātmaja Yādavaśarman, ed.] Maharșiṇā punarvasunopidiṣt ā tacchiṣyeṇāgniveśena pranītā carakadṛdhabalābhyāṃ pratisamskṛ̂ā Carakasaṃitā | śrīcakrapāṇidattaviracitayā Āyurvedadīpikāvyākhyayā samvalitā | ācāryopāhvena trivikramātmajena yādavaśarmaṇā saṃsodhitā | (tṛtīyāuṛttị̣) | mumbayyāṃ satyabhāmābāī pāṇụuranga ityetābhị nirnayasāgaramundraṇālayasya kṛte tatraiva mudrāpayitvā prasiddhiṃ nītā | śakābdaḥ 1863, kristābdaḥ 1941. [Reprinted in 1981 as a fourth edition; New Delhi: Munśīrām Manoharlāl Publishers Pvt. Ltd.].

[Trivikramātmaja Yādavaśarman and Nārāyana Rāma Ācārya 'Kāvyatīrtha,' eds.] Jayakṇṣnādāsa Āyurveda Granthamālā 34 | maharṣiṇā suśrutena viracitā Suśrutasaṃhitā | śrị̄alhaṇācāryaviracitayā Nibandhasamgrahākhyavyākhyayā nidānasthānasya śrīgayadāsācāryaviracitayā Nyāyacandrikākhyapañjikāvyākhyayā ca samullasitā ārambastaś cikitsāsthānasya navamādhyāyaparyantā ācāryopāhvena trivikramātmjena yādavaśarmaṇā śeșā ca nārāyaṇa rāma ācārya 'kāvyatîrtha' ity anena saṃsodhitā | bhūmikā ācārya priyavrata śarmā bhūtapūrvam . . . | Caukhambhā Orientalia ... Vārānasīi/Dillī, 1980 [reprint of 1938 edition].

Upadhyaya, S.C. (trans.) 1961, Kama Sutra of Vatsyayana, Bombay: D.B. Taraporevala Sons and Co. Private Ltd.

- (trans.) 1981, The Hindu Secrets of Love. Kokashastra (Rati Rahasya) of Pandit Kokkoka, Bombay: D.B. Taraporevala Sons \& Co. Private Ltd.

Zysk, K.G. 1998, Asceticism and Healing in Ancient India, Medicine in the Buddhist Monastery, Delhi: Motilal Banarsidass; Indian Medical Tradition, Volume I.

- 1999, 'Mythology and the Brahmanization of Indian Medicine: Transforming 
Heterodoxy into Orthodoxy', in Categorisation and Interpretation, edited by Folke Josephson (Indological and comparative studies from an international indological meeting at the Department of Comparative Philology, Göteborg University) [Meijerbergs Arkiv för Svensk Ordforskning, 24], Göteborg Universitet, 125-45.

. (trans.) 2002, Conjugal Love in India. Ratiśästra and Ratiramana. Text, Translation, and Notes. Leiden, Boston, Köln: E.J. Brill; Sir Henry Wellcome Asian Series, Volume 1. 